\title{
Tuning cell migration: contractility as an integrator of intracellular signals from multiple cues [version 1; peer
} review: 2 approved]

Francois Bordeleau, Cynthia A. Reinhart-King

Meinig School of Biomedical Engineering, Cornell University, Ithaca, NY, USA
V1 First published: 26 Jul 2016, 5(F1000 Faculty Rev):1819

https://doi.org/10.12688/f1000research.7884.1

Latest published: 26 Jul 2016, 5(F1000 Faculty Rev):1819

https://doi.org/10.12688/f1000research.7884.1

\section{Abstract}

There has been immense progress in our understanding of the factors driving cell migration in both two-dimensional and three-dimensional microenvironments over the years. However, it is becoming increasingly evident that even though most cells share many of the same signaling molecules, they rarely respond in the same way to migration cues. To add to the complexity, cells are generally exposed to multiple cues simultaneously, in the form of growth factors and/or physical cues from the matrix. Understanding the mechanisms that modulate the intracellular signals triggered by multiple cues remains a challenge. Here, we will focus on the molecular mechanism involved in modulating cell migration, with a specific focus on how cell contractility can mediate the crosstalk between signaling initiated at cell-matrix adhesions and growth factor receptors.

\section{Keywords}

Contractility , Crosstalk, cell migration, focal adhesions

\section{Open Peer Review}

Approval Status

1

2

version 1

26 Jul 2016

Faculty Reviews are review articles written by the prestigious Members of Faculty Opinions. The articles are commissioned and peer reviewed before publication to ensure that the final, published version is comprehensive and accessible. The reviewers who approved the final version are listed with their names and affiliations.

1. Anand Asthagiri, Northeastern University, Boston, USA

Northeastern University, Boston, USA

2. Gaudenz Danuser, University of Texas Southwestern Medical Center, Dallas, USA University of Texas Southwestern Medical Center, Dallas, USA

Any comments on the article can be found at the end of the article. 
Corresponding author: Cynthia A. Reinhart-King (cak57@cornell.edu)

Competing interests: The authors declare that they have no competing interests.

Grant information: This work was supported by funding from the National Institutes of Health (R01HL427199) and the National Science Foundation (1233827, 1055502, and 1435755) to Cynthia Reinhart-King.

The funders had no role in study design, data collection and analysis, decision to publish, or preparation of the manuscript.

Copyright: @ 2016 Bordeleau F and Reinhart-King CA. This is an open access article distributed under the terms of the Creative Commons Attribution License, which permits unrestricted use, distribution, and reproduction in any medium, provided the original work is properly cited.

How to cite this article: Bordeleau F and Reinhart-King CA. Tuning cell migration: contractility as an integrator of intracellular signals from multiple cues [version 1; peer review: 2 approved] F1000Research 2016, 5(F1000 Faculty Rev):1819 https://doi.org/10.12688/f1000research.7884.1

First published: 26 Jul 2016, 5(F1000 Faculty Rev):1819 https://doi.org/10.12688/f1000research.7884.1 


\section{Introduction}

Cell migration is critical to numerous physiological and pathological conditions, including development, wound healing, and tumor cell metastasis. Cell migration within an organism is seldom solely random but rather is in response to a directed set of signaling cues. Even during diseases such as cancer, migrating cells appear to follow guiding signals ${ }^{1,2}$. The cell microenvironment can provide and support a multitude of different kinds of cues that trigger and direct cell migration ${ }^{2-5}$. In turn, cell migration requires complex, regulating intracellular machinery to accurately respond to the cues and properly interact with the extracellular matrix (ECM). This is highlighted by the fact that not all cells possess the same migrating potential nor do they respond to a given cue in the same way ${ }^{6-9}$.

The ability of adherent cells to migrate is dependent primarily on their ability to dynamically regulate integrin-mediated cell-ECM linkages at specialized focal adhesions (FAs) and hemidesmosome membrane domains ${ }^{10-12}$. The mechanisms and dynamics behind FA formation and maturation are increasingly well documented in both two-dimensional (2D) and threedimensional (3D) matrices ${ }^{12-18}$. Given our present knowledge, these mechanisms appear to be shared by most adherent cells.

Directed cell migration requires proper inputs. These migration cues include biochemical cues present in the form of soluble growth factors and hormones, direct physical stimulation such as shear flow or electrical fields, and the cues arising from the physical and architectural organization of the $\mathrm{ECM}^{19}$. However, a current limitation in our understanding of the true impact of these cues lies in the fact that they are largely studied independently from each other, and most findings are generally cell type specific. There have been some efforts to combine at least two different migration cues (20-22, and reviewed here ${ }^{19}$ ). Additionally, it is not clear why, in a given cell population, cells can exhibit different migration behaviors despite using the same machinery and being subjected to the same pro-migration cues.

Here, in an attempt to explain the migration differences that exist between cells exposed to the same cues, we will explore the major molecular features that finely regulate cell migration. We will first present an overview of the major factors and cues, both extracellular and intracellular, involved in controlling cell migration. We will then focus on mechanisms that can finely tune cell migration for a given set of migration cues and discuss how cell contractility may play a central role in the integration of intracellular signals.

\section{Determinants of cell migration}

Given a specific set of extracellular cues, cell migration is typically a function of the nature (quantity, presentation, and so on) of those cues. Notably, growth factor stimulation can trigger cell migration, and the presence of concentration gradients can enable directed migration through chemotaxis ${ }^{19,23}$. Chemotaxis is a major driver of cell movement and is instrumental during development and for angiogenesis in tumors ${ }^{4,23}$, for example. Since not all cell types respond to the same set of given cues, genetic differences between different cell types may readily explain why some cells have increased affinity for specific chemical cues. For instance, differential expression of growth factor receptor families, including their various isoforms, can prime cells to respond to a specific subset of growth factors. An example is the vascular endothelial growth factor receptor (VEGFR) family, which is normally expressed in cells of vascular origin and where both VEGFR1 and VEGFR2 are potent inducers of endothelial cell migration ${ }^{24}$. Importantly, however, differential expression of growth factor receptors does not always correlate with cell migration during experimental observation ${ }^{7,8}$. A striking example is when comparing the migration induced by different growth factors of highly invasive MDA-MB-231 and the weakly metastatic MCF7 cell lines. For instance, stimulation with the insulinlike growth factor 1 (IGF-1) triggers more potent migration in MDA-MB-231 cells compared with MCF7 cells, and the effects are reversed when epidermal growth factor is used instead ${ }^{7}$. Estrogen receptor-positive tumor cells, such as MCF7 cells, are characterized by overexpression of the IGF-1 receptor ${ }^{25}$, whereas MDA-MB-231 cells are known to overexpress EGFR ${ }^{26}$. Moreover, although the average response of a cell population to growth factor stimulation provides critical information when comparing different cues or cell types, it does not explain the variability between individual cells within a cell population. In fact, not all cells within a population will move efficiently toward the source of a gradient; some cells will not move at all or will go in the opposite direction ${ }^{27,28}$. Therefore, differences in the expression patterns of growth factor receptors are not necessarily sufficient to explain the differences in cell migration observed experimentally.

In comparison with soluble growth factors, migration cues arising from the ECM have traditionally been more difficult to study given the inherent engineering challenge of properly recreating a physiologically relevant ECM scaffold ${ }^{29,30}$. Nevertheless, several groups, including our own, have over the years made several breakthroughs in understanding how the physical properties of the ECM can influence cell migration and provide migration $\mathrm{cues}^{3,17,31,32}$. Some of the early seminal work in this area has been instrumental in showing that cell migration is guided along matrix stiffness heterogeneities and gradients ${ }^{3,33}$. Importantly, recent advances in our ability to control the ECM architecture and its mechanical properties have enabled increased scrutiny of cell migration, especially in the $3 \mathrm{D}$ microenvironments ${ }^{34-36}$. Notably, work within the field has addressed how the 3D architecture of the ECM, including the presence of microtracks or steep ECM interfaces, can impede, facilitate, or provide contact guidance for cell migration ${ }^{17,37-40}$. The various kinds of physical features present in the ECM and their impact on cell migration have recently been reviewed ${ }^{5,41}$. Interestingly, the presence of local heterogeneities in the microarchitecture of the ECM could help explain in part the migration difference between individual cells within a cell population.

Working in concert with the physical ECM and microenvironment, adhesion molecules are the central regulators of cell migration since they are the linkage between the cell and the supporting $\mathrm{ECM}^{12}$. Interestingly, similar observations have been made regarding the expression of cell adhesion proteins, such as the integrin receptors, as with growth factor receptors. That is, integrin expression is not always correlated with migration response and exhibits cell-type-dependent variations ${ }^{42}$. Integrins are $\alpha \beta$ heterodimers and their ligand binding specificity is determined by which integrin subtypes assemble to form a pair (for example, $\alpha 5 \beta 1, \alpha v \beta 3$, and 
$\alpha 4 \beta 1$ for fibronectin; $\alpha 1 \beta 1$ and $\alpha 2 \beta 1$ for collagen; and $\alpha 2 \beta 1$, $\alpha 3 \beta 1$, and $\alpha 6 \beta 4$ for laminins $)^{12}$. Given their large diversity $(18 \alpha$ and $8 \beta$ in 24 different possible pairs ${ }^{43}$, it is easy to assume that they may play a vital role in differentially regulating cells' migration ability. Indeed, in some cases, differential expression of integrin subtypes, such as $\beta 3$, correlates with altered cell migration potential $^{44,45}$. However, this correlation does not hold universally true. For instance, different tumor cell lines can have similar levels of integrin expression and different migration potential ${ }^{46-48}$. There are also examples where cell migration can be regulated by controlling the activation state of integrins or the integrin-mediated downstream signaling ${ }^{13,49-51}$. The signaling initiated by integrins controls several key processes required for migration, including FA turnover and control of actin dynamics ${ }^{52-55}$. Notably, the integrin $\beta 1$ plays a central role in regulating FA dynamics through the activation of the Src/FA kinase (FAK) pair at FAs, which in turn regulates Rac1 and RhoA at the cell front ${ }^{55-57}$. Interestingly, the mechanical properties of the cellular environment regulate an integrin $\beta 1$-mediated activation of specific FA proteins, including FAK $^{13,15,58-60}$. Increasing the stiffness of either 2D or 3D matrices results in higher FAK phosphorylation levels as well as larger FAs in several cell types ${ }^{58,60}$. In addition, these signaling pathways are regulated by both feedback loops and crosstalk with other transmembrane receptors ${ }^{61-64}$.

Therefore, when these results are considered together, migration differences between cells cannot be explained solely by differential expression of the receptors associated with a given cue. In fact, one explanation for why cells display a wide range of migration behaviors may reside in their ability to integrate the different intracellular signals triggered by the available migration cues they experience. In this context, it becomes crucial to better examine the mechanisms that can modulate the signaling triggered by migration cues.

\section{Integration of intracellular signals through cell contractility}

The ability of cells to integrate cues from multiple cues has been studied for many years, often with an emphasis on transmembrane receptor interactions and crosstalk in specific cell membrane domains ${ }^{61,62,65,66}$. Among the best known examples of this are the interactions and crosstalk between integrins and various growth factor receptors ${ }^{61-64}$. EGFR and VEGFR, for example, point to an integrin-mediated role in efficient activation of these receptors ${ }^{61,63,67-69}$. However, an emerging concept is that integrin-growth factor receptor crosstalk is facilitated by cell contractility ${ }^{68,70,71}$. The consequences of this contractility-mediated crosstalk have important ramifications for the ability of cells to integrate migration cues like soluble growth factors and ECM stiffness. It is established that cell contractility is modulated by ECM stiffness ${ }^{68,72}$. For example, increasing ECM stiffness leads to both enhanced smooth muscle cell response to platelet-derived growth factor ${ }^{70,71}$ (see example in Figure 1A) and epithelial cell response to EGF ${ }^{68}$. Interestingly, the interplay between ECM mechanical cues and growth factor signaling appears to be mediated in part by cell contractility. When cell contractility is inhibited through inhibition of the RhoROCK-MLC axis, cell response to growth factors is suppressed. Moreover, cells within a population tend to display a wide range of measureable contractility for a given ECM stiffness ${ }^{73,74}$, which in turn could influence how sensitive each individual cell is to growth factor stimulation. A similar explanation could apply to various cell types that show different contractility levels ${ }^{68,74,75}$.

In addition to being found in the soluble microenvironment, growth factors can be found bound to the matrix and are in fact not always readily accessible ${ }^{65,76,77}$. Transforming growth factor-beta (TGF- $\beta$ ) is an interesting example. It is normally found encapsulated within a latent TGF- $\beta 1$ complex bound to the

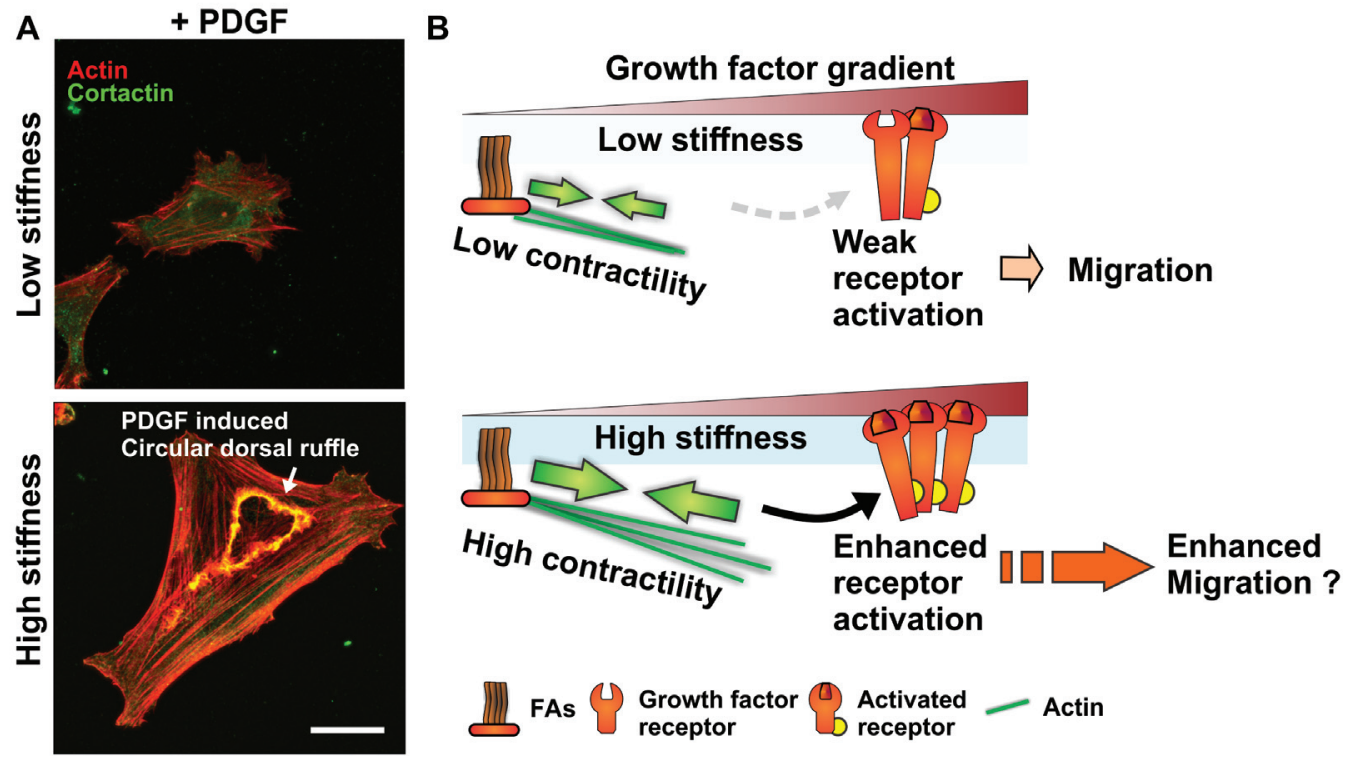

Figure 1. Matrix stiffness-mediated regulation of growth factor activation as a modulator of cell migration. (A) Matrix stiffness regulates the formation of actin and cortactin-rich circular dorsal ruffle structures downstream of platelet-derived growth factor (PDGF) receptor activation in response to PDGF stimulation in smooth muscle cells (low stiffness: $1 \mathrm{kPa}$; high stiffness: $30 \mathrm{kPa}$; see 70 for details). Scale bar is $20 \mu \mathrm{m}$. (B) Schematics of proposed signaling crosstalk between focal adhesion (FA) and growth factor receptors depicting how increased matrix stiffness could potentiate growth factor-induced signaling, resulting in increased cell migration. 
$\mathrm{ECM}^{78}$. This complex contains an RGD sequence that enables integrin binding, and cells capable of generating sufficient force will ultimately be more able to access active TGF- $\beta 1^{79}$. Moreover, the underlying ECM needs to be sufficiently stiff to support the force required to unwind the latent TGF- $\beta 1$ complex, which would otherwise deform, dissipating the force without releasing the stored TGF- $\beta^{79}$. Overall, these results suggest that cell migratory response to growth factor cues may in fact be ultimately linked to the interplay between ECM stiffness and the contractile state of the cell (Figure 1B).

An interesting prediction arising from the studies described above is that cells on stiffer substrates could exhibit increased migratory response in the presence of a growth factor gradient in a process that could be cell type specific. There has been some work using numerical modeling of the integration of migration cues to predict migration response; however, these models contain the assumption that the cues are purely additive from the perspective of the cell ${ }^{80}$. However, they do not address how each of these cues could synergize or interfere with one another since their work is based on experimental data where each of these cues is studied in isolation $^{81,82}$.

Indeed, one of the challenges in this work is to assess whether cues are additive or whether the signaling triggered by one cue alters the response to the other cues. Notably, different migration cues can either directly compete or cooperate with each other ${ }^{20-22,83}$. Work done to elucidate the link between the ECM and growth factor stimulation can provide some mechanistic insight into how different cues may lead to completely different biological outcomes. For example, there is a critical ECM stiffness at which TGF- $\beta 1$ stimulation switches from being pro-apoptotic to proepithelial to mesenchymal transition ${ }^{84}$. ECM stiffness can also promote an EGF-dependent change toward a "malignant" phenotype in mammary epithelial cells ${ }^{58,68}$. Interestingly, the phenotypical changes observed in mammary cells in response to ECM stiffness and EGF were dependent on FAK and ERK co-activation, whereas altering cell contractility state overrides the system ${ }^{58,68}$. In this context, there are likely regulating signaling components, particularly those modulating both the cell contractile state and cell interactions with the ECM, that ultimately play a central role to integrate various extracellular cues.

\section{Tuning cell migration by modulating focal adhesion signaling nodes}

With regard to the signaling that controls cell migration and contractility, most of the work that has been performed has focused on key components that are ubiquitously expressed in almost all cells. These key components are usually master regulators that act as an on/off switch such as the Rho GTPases as well as FAK, PI3K, and Src family kinases ${ }^{57,85-90}$. Importantly, though, both proper activation and localization of these proteins are instrumental in modulating cell migration ${ }^{13,85,91-93}$. One way to regulate the FAK/Src signaling initiated at FAs is through feedback loops ${ }^{64}$. For example, members of the protein kinase $\mathrm{C}$ (PKC) family can be activated upon cell adhesion to fibronectin along with FAK; in turn, increased PKC activity leads to increased activation of $\alpha 5 \beta 1$ integrins and cross-activation of the $\alpha 4 \beta 1$ integrins, essentially leading to more FAK activation in a feed-forward loop ${ }^{64}$. It is interesting to note that such PKC-mediated integrin regulation exists in several other cell types. Notably, PKC $\varepsilon$ positively regulates integrin-dependent cell migration in gliomas cells, whereas PKC $\alpha$ plays an opposite role $^{94}$. Study of renal carcinoma cell migration suggests instead a PKC $\delta$-dependent mediation ${ }^{95}$. In addition, PKCs are often found downstream of growth factor receptor activation ${ }^{96-99}$. Notably, these studies also suggest that $\mathrm{PKC}$ isoform-mediated cell migration regulation is cell type dependent, even though PKC isoforms are roughly expressed at comparable levels in most tissues (GeneAtlas U133A, gcrma $\left.^{100,101}\right)$. Therefore, there must exist cellular mechanisms to enable fine-tuning of cell migration by the various PKC isoforms.

Indeed, the ability of PKCs to modulate cell adhesion and migration depends on their association with intermediary proteins. For example, the receptor for activated C-kinase (RACK1) enables the interaction of PKC $\varepsilon$ with $\beta 1$ integrin to promote glioma cell adhesion and migration ${ }^{94}$, and $\mathrm{PKCs}$ can also modulate Src activity via RACK $1{ }^{102}$. In addition, PKC-mediated modulation of cell migration can be further tuned by the intermediate filament (IF) cytoskeleton expression profile of cells ${ }^{13,103}$. Notably, PKCE mediates integrin recycling and is required for efficient migration when cells express vimentin ${ }^{103}$, an IF found in cells of mesenchymal origin and highly aggressive carcinomas ${ }^{104}$. Alternatively, the expression of the keratin 8/18 IF pair, which is a hallmark of all simple epithelia, enables more efficient PKC $\delta$ activation of FAK, which in turn promotes more directed cell migration ${ }^{13}$. Of note, the absence of the keratin 8/18 IF appears to alter the formation of the PKC/RACK1 complex, where $\mathrm{PKC} \delta$ is replaced by $\mathrm{PKC}^{13}$. Most interestingly, recent work has shown that Rac1-mediated phosphorylation of the myosin heavy chain IIa at the front of the cell and in FAs is PKC dependent ${ }^{105}$. It also appears that this specific myosin heavy chain phosphorylation mechanism helps to regulate both cell migration and mechanosensing ${ }^{105}$. Moreover, we and others have recently shown that IFs are important modulators of cell contractility $^{73,106-108}$. Therefore, small differences in FA signaling node organization might be sufficient to alter the crosstalk between integrins and growth factor receptors and explain the diversity of cell-type-specific response to migration cues (Figure 2). Overall, understanding how these scaffolding components can modulate major signaling pathways may provide key insights into celltype-specific response differences to migration cues.

\section{A role for epigenetics and microRNA regulation in fine-tuning cell migration}

An emerging and exciting area in cell migration research is how epigenetics may tie into the regulation of cell migration and the integration of different migration cues. Protein expression control through alternative splicing appears to be one such mechanism. Alternative splicing is a primary source of protein diversity, where one gene can generate multiple different versions of a protein ${ }^{109,110}$. Several proteins that possess alternatively spliced variants are linked to cell migration, including signaling proteins (such as $\beta 1$ integrin, Rho GTPase, FAK, and PKCs) $)^{11-113}$, scaffolding and structural proteins (plectin, cortactin, and p130CAS) $)^{114-116}$, growth factors $\left(\right.$ TGF- $\beta$ and VEGF) ${ }^{117,118}$, and ECM components (fibronectin) ${ }^{119}$. 


\section{Cell type $1 \quad$ Growth factor gradient}

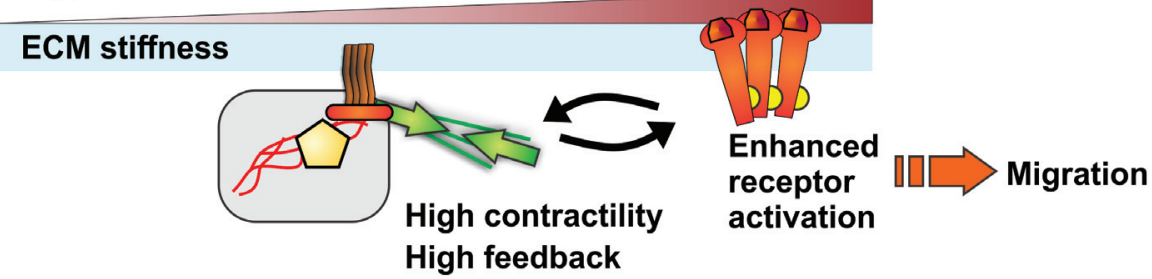

\section{Cell type 2}

ECM stiffness

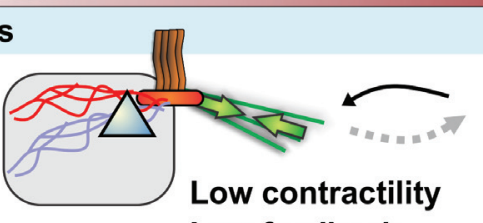

Low feedback

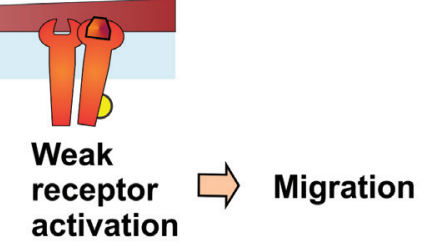

\section{Cell type 3}

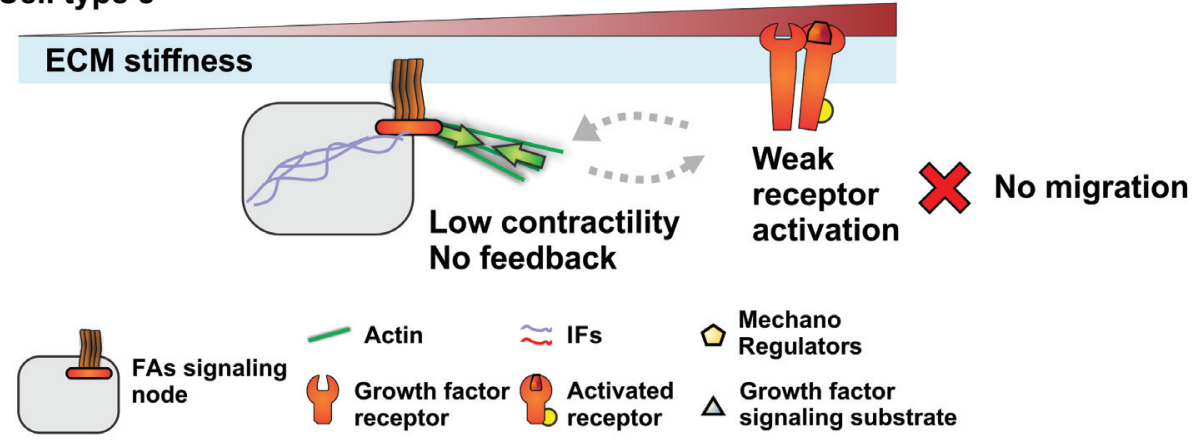

Figure 2. Focal adhesion (FA) signaling nodes and their potential role in modulating response to growth factors and subsequent cell migration. Schematics showing how the expression of different forms of mechanoregulating and scaffolding proteins in three cell types can influence intracellular signal integration by altering signaling nodes. Differential expression of these factors can alter the contractile state of the cell or directly enhance the feedback between growth factor receptors and FAs, resulting in a modulated response to growth factor stimulation that could regulate migration. These mechanoregulators can be structural and scaffolding proteins, such as different intermediate filaments (IFs), or signaling kinases, such as protein kinase C, or both. ECM, extracellular matrix.

The alternate versions of these proteins can have distinct functions compared with their canonical counterpart, resulting in altered cell behaviors, including migration ${ }^{15,117}$. Therefore, alternative splicing could play an important role in modulating migration cues and signal integration by altering signaling nodes and migration effectors. Interestingly, our recent work indicates that the interplay between matrix stiffness and cell contractility regulates alternative splicing of proteins produced by the cell ${ }^{120}$. The implications of these findings with regard to signal integration of multiple cues are potentially significant since they suggest that cells have a selftuning mechanism. Another highly relevant epigenetic mechanism worth exploring is the involvement of microRNA (miRNA). Indeed, recent work has linked the expression of several miRNAs to the ability of cells to integrate ECM mechanical cues as well as regulate cell migration ${ }^{121,122}$. Both of these aspects remain largely understudied and underappreciated.

\section{Designing experimental approaches to resolve signal integration to multiple cues}

Our ability to move forward in the study of systems that combine multiple cues relies on our ability to engineer devices that can dynamically combine these cues in a controlled manner so that the cell response to these cues can be analyzed. A number of groups have designed such devices, where they recapitulate some of the characteristics of the ECM or the cellular microenvironment, the presence of chemical cues, or even cell-cell interactions $\mathrm{s}^{27,83,123}$. These engineered approaches range from simple tuning of ECM mechanical features ${ }^{70,84}$ to microfluidic devices that allow for the integration of multiple cues ${ }^{27,83}$. However, the numerous crosstalk and compensatory mechanisms that are likely triggered by multiple simultaneous input cues make it difficult to dissect the relevant signal transduction pathways, especially for signaling proteins that are involved in multiple pathways. Even stimulation from a 
single input can activate numerous different signaling pathways that are dependent on protein expression levels or the presence of point mutations ${ }^{13,96,124}$. Therefore, a more integrative approach to study cellular systems in the presence of multiples migration cues should include temporal and spatial analysis of the multiple signaling nodes in cells as well as cell contractility and downstream migratory events. Importantly, determining how and when different compensation mechanisms get activated when cells are subjected to multiple cues is critical to understanding intervention points for drug therapies.

Interestingly, it is possible to dissect dynamic cellular responses to different perturbations by using a time series modeling approach ${ }^{125}$. This particular modeling approach yields information on how and when cells can switch between different phenotypic states. Such an approach permits multiple inputs and output states, allowing a more holistic characterization of how cells integrate signals from multiple cues. A clustering approach can also be used to analyze signaling networks in cells subjected to different stimuli to help distinguish between shared pathways between receptors and reveal the response of specific classes of receptors to soluble factors ${ }^{126}$. In addition, modeling approaches of signaling networks in the form of regulatory circuits can account for coupling and compensatory mechanisms ${ }^{127}$. For example, modeling of regulatory circuits can describe the contribution of miRNAs and transcription factors in the coupling of signaling networks and can predict the migration mode adopted by tumor cells ${ }^{128}$. Therefore, these modeling approaches are powerful tools to help identify compensatory mechanisms occurring in experimental systems and adequately describe the different possible states within a cell population.

\section{Summary}

Although observations described in the literature can help explain how cell migration can be more finely tuned depending on the cellular and microenvironmental context, they do not yet offer a complete picture of how cells integrate various migration cues. What we do know about the mechanisms that govern cell migration only serves to underscore the complexity of the system, particularly in cases where there is more than one input signal. By increasing our comprehension of how cells can differentially integrate multiple signals to finely tune cell behavior, we may be able to gain greater control over complex cellular systems and address the discrepancies between what we know of cell migration and the actual experimental observations across different cell populations. Ultimately, this knowledge will facilitate the design and improvement of bioengineered scaffolds and aid in the development of more personalized and disease-specific treatments.

\section{Competing interests}

The authors declare that they have no competing interests.

\section{Grant information}

This work was supported by funding from the National Institutes of Health (R01HL427199) and the National Science Foundation (1233827, 1055502, and 1435755) to Cynthia Reinhart-King.

The funders had no role in study design, data collection and analysis, decision to publish, or preparation of the manuscript.
1. Friedl P, Alexander S: Cancer invasion and the microenvironment: plasticity and reciprocity. Cell. 2011; 147(5): 992-1009. PubMed Abstract | Publisher Full Text

2. Weigelin B, Bakker GJ, Friedl P: Intravital third harmonic generation microscopy of collective melanoma cell invasion. Intravital. 2012; 1(1): 32-43. Publisher Full Text

3. Lo CM, Wang HB, Dembo M, et al:: Cell movement is guided by the rigidity of the substrate. Biophys J. 2000; 79(1): 144-52. PubMed Abstract | Publisher Full Text | Free Full Text

4. Bravo-Cordero JJ, Hodgson L, Condeelis J: Directed cell invasion and migration during metastasis. Curr Opin Cell Biol. 2012; 24(2): 277-83. PubMed Abstract | Publisher Full Text | Free Full Text

5. $\quad F$ Keely $P$, Nain A: Capturing relevant extracellular matrices for investigating cell migration [version 1; referees: 2 approved]. F1000Res. 2015; 4. pii: F1000 Faculty Rev-1408.

PubMed Abstract | Publisher Full Text | Free Full Text | F1000 Recommendation

6. Physical Sciences - Oncology Centers Network, Agus DB, Alexander JF, et al.: A physical sciences network characterization of non-tumorigenic and metastatic cells. Sci Rep. 2013; 3: 1449. PubMed Abstract | Publisher Full Text | Free Full Text

7. Mezi S, Todi L, Orsi E, et al:: Involvement of the Src-cortactin pathway in migration induced by IGF-1 and EGF in human breast cancer cells. Int $\mathrm{J}$ Oncol. 2012; 41(6): 2128-38.

PubMed Abstract | Publisher Full Text

8. F Bourgeois DL, Kabarowski KA, Porubsky VL, et al:: High-grade serous ovarian cancer cell lines exhibit heterogeneous responses to growth facto stimulation. Cancer Cell Int. 2015; 15: 112. PubMed Abstract | Publisher Full Text | Free Full Text | F1000 Recommendation F Pathak A, Kumar S: Transforming potential and matrix stiffness co-regulate confinement sensitivity of tumor cell migration. Integr Biol (Camb). 2013; 5(8): 1067-75.

PubMed Abstract | Publisher Full Text | Free Full Text | F1000 Recommendation

10. Parsons JT, Horwitz AR, Schwartz MA: Cell adhesion: integrating cytoskeletal dynamics and cellular tension. Nat Rev Mol Cell Biol. 2010; 11(9): 633-43. PubMed Abstract | Publisher Full Text | Free Full Text

11. Litjens SH, de Pereda JM, Sonnenberg A: Current insights into the formation and breakdown of hemidesmosomes. Trends Cell Biol. 2006; 16(7): 376-83. PubMed Abstract | Publisher Full Text

12. Huttenlocher A, Horwitz AR: Integrins in cell migration. Cold Spring Harb Perspect Biol 2011; 3(9): a005074.

PubMed Abstract | Publisher Full Text | Free Full Text

13. Bordeleau F, Galarneau L, Gilbert S, et al.: Keratin $8 / 18$ modulation of protein kinase $\mathrm{C}$-mediated integrin-dependent adhesion and migration of liver epithelial cells. Mol Biol Cell. 2010; 21(10): 1698-713. PubMed Abstract | Publisher Full Text | Free Full Text

14. F Yeung T, Georges PC, Flanagan LA, et al: Effects of substrate stiffness on cell morphology, cytoskeletal structure, and adhesion. Cell Motil Cytoskeleton. 2005; 60(1): 24-34

PubMed Abstract | Publisher Full Text | F1000 Recommendation

15. F Webb DJ, Donais K, Whitmore LA, et al:: FAK-Src signalling through paxillin, ERK and MLCK regulates adhesion disassembly. Nat Cell Biol. 2004; 6(2): 154-61.

PubMed Abstract | Publisher Full Text | F1000 Recommendation

16. Tolde $O$, Rösel $D$, Janoštiak R, et al.: Dynamics and morphology of focal adhesions in complex 3D environment. Folia Biol (Praha). 2012; 58(5): 177-84. PubMed Abstract 
17. Bordeleau F, Tang LN, Reinhart-King CA: Topographical guidance of 3D tumor cell migration at an interface of collagen densities. Phys Biol. 2013; 10(6): 065004

PubMed Abstract | Publisher Full Text | Free Full Text

18. F Chiu CL, Aguilar JS, Tsai CY, et al:: Nanoimaging of focal adhesion dynamics in 3D. PLoS One. 2014; 9(6): e99896.

PubMed Abstract | Publisher Full Text | Free Full Text | F1000 Recommendation

19. Lara Rodriguez L, Schneider IC: Directed cell migration in multi-cue environments. Integr Biol (Camb). 2013; 5(11): 1306-23. PubMed Abstract | Publisher Full Text

20. Sundararaghavan HG, Saunders RL, Hammer DA, et al.: Fiber alignment directs cell motility over chemotactic gradients. Biotechnol Bioeng. 2013; 110(4) 1249-54

PubMed Abstract | Publisher Full Text

21. Haessler $U$, Pisano M, Wu M, et al: Dendritic cell chemotaxis in 3D under defined chemokine gradients reveals differential response to ligands CCL21 and CCL19. Proc Natl Acad Sci U S A. 2011; 108(14): 5614-9. PubMed Abstract | Publisher Full Text | Free Full Text

22. Hale NA, Yang Y, Rajagopalan P: Cell migration at the interface of a dua chemical-mechanical gradient. ACS Appl Mater Interfaces. 2010; 2(8): 2317-24. PubMed Abstract | Publisher Full Text

23. Roussos ET, Condeelis JS, Patsialou A: Chemotaxis in cancer. Nat Rev Cancer. 2011; 11(8): 573-87.

PubMed Abstract | Publisher Full Text | Free Full Text

24. Shibuya M: Vascular Endothelial Growth Factor (VEGF) and Its Receptor (VEGFR) Signaling in Angiogenesis: A Crucial Target for Anti- and ProAngiogenic Therapies. Genes Cancer. 2011; 2(12): 1097-105.

PubMed Abstract | Publisher Full Text | Free Full Text

25. Jackson JG, White MF, Yee D: Insulin receptor substrate-1 is the predominant signaling molecule activated by insulin-like growth factor-I, insulin, and interleukin-4 in estrogen receptor-positive human breast cancer cells. J Biol Chem. 1998; 273(16): 9994-10003.

PubMed Abstract | Publisher Full Tex

26. Davidson NE, Gelmann EP, Lippman ME, et al:: Epidermal growth factor receptor gene expression in estrogen receptor-positive and negative human breast cancer cell lines. Mol Endocrinol. 1987; 1(3): 216-23. PubMed Abstract | Publisher Full Text

27. Zervantonakis IK, Hughes-Alford SK, Charest JL, et al.: Three-dimensiona microfluidic model for tumor cell intravasation and endothelial barrier function. Proc Natl Acad Sci U S A. 2012; 109(34): 13515-20. PubMed Abstract | Publisher Full Text | Free Full Text

28. Bajpai S, Mitchell MJ, King MR, et al:: A microfluidic device to select for cells based on chemotactic phenotype. Technology (Singap World Sci). 2014; 2(2): 101-5.

PubMed Abstract | Publisher Full Text | Free Full Text

29. Mason BN, Reinhart-King CA: Controlling the mechanical properties of threedimensional matrices via non-enzymatic collagen glycation. Organogenesis. 2013; 9(2): 70-5.

PubMed Abstract | Publisher Full Text | Free Full Text

30. Bajpai S, Kim NY, Reinhart-King CA: Approaches to manipulating the dimensionality and physicochemical properties of common cellular scaffolds. Int J Mol Sci. 2011; 12(12): 8596-609.

PubMed Abstract | Publisher Full Text | Free Full Text

31. Carey SP, Kraning-Rush CM, Williams RM, et al:: Biophysical control of invasive tumor cell behavior by extracellular matrix microarchitecture. Biomaterials. 2012; 33(16): 4157-65.

PubMed Abstract | Publisher Full Text | Free Full Text

32. F Raab M, Swift J, Dingal PC, et al.: Crawling from soft to stiff matrix polarizes the cytoskeleton and phosphoregulates myosin-II heavy chain. J Cell Biol. 2012; 199(4): 669-83.

PubMed Abstract | Publisher Full Text | Free Full Text | F1000 Recommendation

33. Gray DS, Tien J, Chen CS: Repositioning of cells by mechanotaxis on surfaces with micropatterned Young's modulus. J Biomed Mater Res A. 2003; 66(3): 605-14.

PubMed Abstract | Publisher Full Text

34. Hapach LA, VanderBurgh JA, Miller JP, et al:: Manipulation of in vitro collagen matrix architecture for scaffolds of improved physiological relevance. Phys Biol. 2015; 12(6): 061002

PubMed Abstract | Publisher Full Text

35. Gillette BM, Rossen NS, Das N, et al:: Engineering extracellular matrix structure in 3D multiphase tissues. Biomaterials. 2011; 32(32): 8067-76. PubMed Abstract | Publisher Full Text | Free Full Text

36. Charest JM, Califano JP, Carey SP, et al: Fabrication of substrates with defined mechanical properties and topographical features for the study of cell migration. Macromol Biosci. 2012; 12(1): 12-20. PubMed Abstract | Publisher Full Text

37. Mason BN, Starchenko A, Williams RM, et al:: Tuning three-dimensiona collagen matrix stiffness independently of collagen concentration modulates endothelial cell behavior. Acta Biomater. 2013; 9(1): 4635-44. PubMed Abstract | Publisher Full Text | Free Full Text

38. Kraning-Rush CM, Carey SP, Lampi MC, et al:: Microfabricated collagen tracks facilitate single cell metastatic invasion in 3D. Integr Biol (Camb). 2013; 5(3):
606-16.

PubMed Abstract | Publisher Full Text | Free Full Text

39. Balzer EM, Tong Z, Paul CD, et al.: Physical confinement alters tumor cell adhesion and migration phenotypes. FASEB J. 2012; 26(10): 4045-56. PubMed Abstract | Publisher Full Text | Free Full Text

40. Pathak A, Kumar S: Independent regulation of tumor cell migration by matrix stiffness and confinement. Proc Natl Acad Sci U S A. 2012; 109(26): 10334-9. PubMed Abstract | Publisher Full Text | Free Full Text

41. Bordeleau F, Alcoser TA, Reinhart-King CA: Physical biology in cancer. 5. The rocky road of metastasis: the role of cytoskeletal mechanics in cell migratory response to 3D matrix topography. Am J Physiol Cell Physiol. 2014; 306(2): C110-20.

PubMed Abstract | Publisher Full Text | Free Full Text

42. Friedl $P$, Zänker KS, Bröcker EB: Cell migration strategies in 3-D extracellular matrix: differences in morphology, cell matrix interactions, and integrin function. Microsc Res Tech. 1998; 43(5): 369-78.

PubMed Abstract | Publisher Full Text

43. Shattil SJ, Kim C, Ginsberg MH: The final steps of integrin activation: the end game. Nat Rev Mol Cell Biol. 2010; 11(4): 288-300. PubMed Abstract | Publisher Full Text | Free Full Text

44. Seftor RE, Seftor EA, Gehlsen KR, et al.: Role of the alpha v beta 3 integrin in human melanoma cell invasion. Proc Natl Acad Sci U S A. 1992; 89(5): 1557-61. PubMed Abstract | Publisher Full Text | Free Full Text

45. Palecek SP, Loftus JC, Ginsberg MH, et al.: Integrin-ligand binding properties govern cell migration speed through cell-substratum adhesiveness. Nature. 1997; 385(6616): 537-40

PubMed Abstract | Publisher Full Text

46. Taherian A, Li X, Liu Y, et al:: Differences in integrin expression and signaling within human breast cancer cells. BMC Cancer. 2011; 11: 293. PubMed Abstract | Publisher Full Text | Free Full Text

47. Fisher KE, Pop A, Koh W, et al.: Tumor cell invasion of collagen matrices requires coordinate lipid agonist-induced G-protein and membrane-type matrix metalloproteinase-1-dependent signaling. Mol Cancer. 2006; 5: 69. PubMed Abstract | Publisher Full Text | Free Full Text

48. Chen M, Towers LN, O'Connor KL: LPA2 (EDG4) mediates Rho-dependent chemotaxis with lower efficacy than LPA1 (EDG2) in breast carcinoma cells. Am J Physiol Cell Physiol. 2007; 292(5): C1927-33. PubMed Abstract | Publisher Full Text

49. F Park EJ, Mora JR, Carman CV, et al: Aberrant activation of integrin $\alpha_{4} \beta_{7}$ suppresses lymphocyte migration to the gut. J Clin Invest. 2007; 117(9): 2526-38. PubMed Abstract | Publisher Full Text | Free Full Text | F1000 Recommendation

50. Gawecka JE, Young-Robbins SS, Sulzmaier FJ, et al.: RSK2 protein suppresses integrin activation and fibronectin matrix assembly and promotes cell migration. J Biol Chem. 2012; 287(52): 43424-37. PubMled Abstract | Publisher Full Text | Free Full Text

51. F Shen B, Estevez B, Xu Z, et al.: The interaction of $\mathrm{G} \alpha_{13}$ with integrin $\boldsymbol{\beta}_{1}$ mediates cell migration by dynamic regulation of RhoA. Mol Biol Cell. 2015; 26(20): 3658-70.

PubMed Abstract | Publisher Full Text | Free Full Text | F1000 Recommendation

52. Galbraith CG, Yamada KM, Sheetz MP: The relationship between force and focal complex development. J Cell Biol. 2002; 159(4): 695-705. PubMed Abstract | Publisher Full Text | Free Full Text

53. F de Rooij J, Kerstens A, Danuser G, et al:: Integrin-dependent actomyosin contraction regulates epithelial cell scattering. J Cell Biol. 2005; 171(4): 153-64. PubMed Abstract | Publisher Full Text | Free Full Text | F1000 Recommendation

54. Hamadi A, Bouali M, Dontenwill M, et al.: Regulation of focal adhesion dynamics and disassembly by phosphorylation of FAK at tyrosine 397. J Cell Sci. 2005; 118(Pt 19): 4415-25.

PubMed Abstract | Publisher Full Text

55. Mitra SK, Schlaepfer DD: Integrin-regulated FAK-Src signaling in normal and cancer cells. Curr Opin Cell Biol. 2006; 18(5): 516-23. PubMed Abstract | Publisher Full Text

56. F Schober M, Raghavan S, Nikolova M, et al.: Focal adhesion kinase modulates tension signaling to control actin and focal adhesion dynamics. J Cell Biol. 2007; 176(5): 667-80.

PubMed Abstract | Publisher Full Text | Free Full Text | F1000 Recommendation

57. Huveneers S, Danen EH: Adhesion signaling - crosstalk between integrins, Src and Rho. J Cell Sci. 2009; 122(Pt 8): 1059-69. PubMed Abstract | Publisher Full Text

58. Provenzano PP, Inman DR, Eliceiri KW, et al.: Matrix density-induced mechanoregulation of breast cell phenotype, signaling and gene expression through a FAK-ERK linkage. Oncogene. 2009; 28(49): 4326-43. PubMed Abstract | Publisher Full Text | Free Full Text

59. Tomar A, Lim ST, Lim Y, et al:: A FAK-p120RasGAP-p190RhoGAP complex regulates polarity in migrating cells. J Cell Sci. 2009; 122(Pt 11): 1852-62. PubMed Abstract | Publisher Full Text | Free Full Text

60. Wei WC, Lin HH, Shen MR, et al:: Mechanosensing machinery for cells under low substratum rigidity. Am J Physiol Cell Physiol. 2008; 295(6): C1579-89. PubMed Abstract | Publisher Full Text

61. Gilcrease MZ, Zhou X, Lu X, et al:: Alpha6beta4 integrin crosslinking induces EGFR clustering and promotes EGF-mediated Rho activation in breast cancer. 
J Exp Clin Cancer Res. 2009; 28: 67.

PubMed Abstract | Publisher Full Text | Free Full Text

62. Azimifar SB, Böttcher RT, Zanivan S, et al.: Induction of membrane circular dorsal ruffles requires co-signalling of integrin-ILK-complex and EGF receptor. J Cell Sci. 2012; 125(Pt 2): 435-48.

PubMed Abstract | Publisher Full Text

63. Masson-Gadais $\mathrm{B}$, Houle $\mathrm{F}$, Laferrière $\mathrm{J}$, et al:: Integrin alphavbeta3, requirement for VEGFR2-mediated activation of SAPK2/p38 and for Hsp90-dependent phosphorylation of focal adhesion kinase in endothelial cells activated by VEGF. Cell Stress Chaperones. 2003; 8(1): 37-52. PubMed Abstract | Free Full Text

64. Disatnik $\mathrm{MH}$, Rando TA: Integrin-mediated muscle cell spreading. The role of protein kinase $\mathrm{c}$ in outside-in and inside-out signaling and evidence of integrin cross-talk. J Biol Chem. 1999; 274(45): 32486-92. PubMed Abstract | Publisher Full Text

65. Rahman S, Patel Y, Murray J, et al:: Novel hepatocyte growth factor (HGF) binding domains on fibronectin and vitronectin coordinate a distinct and amplified Met-integrin induced signalling pathway in endothelial cells. $B M C$ Cell Biol. 2005; 6(1): 8 .

PubMed Abstract | Publisher Full Text | Free Full Text

66. Bethani I, Skånland SS, Dikic I, et al:: Spatial organization of transmembrane receptor signalling. EMBO J. 2010; 29(16): 2677-88.

PubMed Abstract | Publisher Full Text | Free Full Text

67. Kuwada SK, Li X: Integrin alpha5/beta1 mediates fibronectin-dependent epithelial cell proliferation through epidermal growth factor receptor activation. Mol Biol Cell. 2000; 11(7): 2485-96.

PubMed Abstract | Publisher Full Text | Free Full Text

68. F Paszek MJ, Zahir N, Johnson KR, et al:: Tensional homeostasis and the malignant phenotype. Cancer Cell. 2005; 8(3): 241-54. PubMed Abstract | Publisher Full Text | F1000 Recommendation

69. Asthagiri AR, Reinhart CA, Horwitz AF, et al.: The role of transient ERK2 signals in fibronectin- and insulin-mediated DNA synthesis. J Cell Sci. 2000; 113 Pt 24: 4499-510.

PubMed Abstract

70. Huynh J, Bordeleau F, Kraning-Rush CM, et al:: Substrate Stiffness Regulates PDGF-Induced Circular Dorsal Ruffle Formation Through MLCK. Cell Mol Bioeng. 2013; 6(2): 138-147.

PubMed Abstract | Publisher Full Text | Free Full Text

71. Zeng $Y$, Lai $T$, Koh CG, et al:: Investigating circular dorsal ruffles through varying substrate stiffness and mathematical modeling. Biophys J. 2011; 101(9): 2122-30

PubMed Abstract | Publisher Full Text | Free Full Text

72. Kraning-Rush $\mathrm{CM}$, Carey SP, Califano JP, et al.: Quantifying traction stresses in adherent cells. Methods Cell Biol. 2012; 110: 139-78.

PubMed Abstract | Publisher Full Text

73. Bordeleau F, Myrand Lapierre M, Sheng $Y$, et al:: Keratin 8/18 regulation of cell stiffness-extracellular matrix interplay through modulation of Rho-mediated actin cytoskeleton dynamics. PLoS One. 2012; 7(6): e38780. PubMed Abstract | Publisher Full Text | Free Full Text

74. Fu J, Wang Y, Yang MT, et al.: Mechanical regulation of cell function with geometrically modulated elastomeric substrates. Nat Methods. 2010; 7(9): 733-6.

PubMed Abstract | Publisher Full Text | Free Full Text

75. Kraning-Rush CM, Califano JP, Reinhart-King CA: Cellular traction stresses increase with increasing metastatic potential. PLoS One. 2012; 7(2): e32572. PubMed Abstract | Publisher Full Text | Free Full Text

76. Wijelath ES, Rahman S, Namekata M, et al:: Heparin-II domain of fibronectin is a vascular endothelial growth factor-binding domain: enhancement of VEGF biological activity by a singular growth factor/matrix protein synergism. Circ Res. 2006; 99(8): 853-60.

PubMed Abstract | Publisher Full Text | Free Full Text

77. Schultz GS, Wysocki A: Interactions between extracellular matrix and growth factors in wound healing. Wound Repair Regen. 2009; 17(2): 153-62. PubMed Abstract | Publisher Full Text

78. Todorovic V, Rifkin DB: LTBPs, more than just an escort service. J Cell Biochem 2012; 113(3): 410-8.

PubMed Abstract | Publisher Full Text | Free Full Text

79. F Klingberg F, Chow ML, Koehler A, et al.: Prestress in the extracellular matrix sensitizes latent TGF-ק1 for activation. J Cell Biol. 2014; 207(2): 283-97. PubMed Abstract | Publisher Full Text | Free Full Text | F1000 Recommendation

80. Mousavi SJ, Doweidar MH, Doblaré M: 3D computational modelling of cell migration: a mechano-chemo-thermo-electrotaxis approach. J Theor Biol. 2013; 329: 64-73.

PubMed Abstract | Publisher Full Text

81. Bosgraaf $L$, Van Haastert PJ: Navigation of chemotactic cells by parallel signaling to pseudopod persistence and orientation. PLoS One. 2009; 4(8): e6842.

PubMed Abstract | Publisher Full Text | Free Full Text

82. Nishimura KY, Isseroff RR, Nuccitelli R: Human keratinocytes migrate to the negative pole in direct current electric fields comparable to those measured in mammalian wounds. J Cell Sci. 1996; 109(Pt 1):199-207. PubMed Abstract
83. $\mathrm{F}$ Lin $\mathrm{B}, \mathrm{Yin} \mathrm{T}, \mathrm{Wu} \mathrm{Yl}$, et al.: Interplay between chemotaxis and contact inhibition of locomotion determines exploratory cell migration. Nat Commun. 2015; 6: 6619 .

PubMed Abstract | Publisher Full Text | Free Full Text | F1000 Recommendation

84. F Leight JL, Wozniak MA, Chen S, et al:: Matrix rigidity regulates a switch between TGF- $\beta 1$-induced apoptosis and epithelial-mesenchymal transition. Mol Biol Cell. 2012; 23(5): 781-91.

PubMed Abstract | Publisher Full Text | Free Full Text | F1000 Recommendation

85. Devreotes $\mathrm{P}$, Horwitz AR: Signaling networks that regulate cell migration. Cold Spring Harb Perspect Biol. 2015; 7(8): a005959. PubMled Abstract | Publisher Full Text

86. Zhao X, Guan JL: Focal adhesion kinase and its signaling pathways in cell migration and angiogenesis. Adv Drug Deliv Rev. 2011; 63(8): 610-5. PubMed Abstract | Publisher Full Text | Free Full Text

87. $\mathrm{F}$ Levental $\mathrm{KR}, \mathrm{Yu} \mathrm{H}$, Kass $\mathrm{L}$, et al.: Matrix crosslinking forces tumor progression by enhancing integrin signaling. Cell. 2009; 139(5): 891-906. PubMed Abstract | Publisher Full Text | Free Full Text | F1000 Recommendation

88. Tomar A, Schlaepfer DD: Focal adhesion kinase: switching between GAPs and GEFs in the regulation of cell motility. Curr Opin Cell Biol. 2009; 21(5): 676-83. PubMed Abstract | Publisher Full Text | Free Full Text

89. Vicente-Manzanares M, Choi CK, Horwitz AR: Integrins in cell migration -- the actin connection. J Cell Sci. 2009; 122(pt 2): 199-206. PubMed Abstract | Publisher Full Text | Free Full Text

90. Qian Y, Zhong X, Flynn DC, et al.: ILK mediates actin filament rearrangements and cell migration and invasion through PI3K/Akt/Rac1 signaling. Oncogene. 2005; 24(19): 3154-65.

PubMed Abstract | Publisher Full Text

91. Doan AT, Huttenlocher A: RACK1 regulates Src activity and modulates paxillin dynamics during cell migration. Exp Cell Res. 2007; 313(12): 2667-79. PubMed Abstract | Publisher Full Text | Free Full Text

92. F Pasapera AM, Schneider IC, Rericha E, et al.: Myosin II activity regulates vinculin recruitment to focal adhesions through FAK-mediated paxillin phosphorylation. J Cell Biol. 2010; 188(6): 877-90.

PubMed Abstract | Publisher Full Text | Free Full Text | F1000 Recommendation

93. Amano M, Nakayama M, Kaibuchi K: Rho-kinase/ROCK: A key regulator of the cytoskeleton and cell polarity. Cytoskeleton (Hoboken). 2010; 67(9): 545-54. PubMed Abstract | Publisher Full Text | Free Full Text

94. Besson A, Wilson TL, Yong VW: The anchoring protein RACK1 links protein kinase Cepsilon to integrin beta chains. Requirements for adhesion and motility. J Biol Chem. 2002; 277(24): 22073-84.

PubMed Abstract | Publisher Full Text

95. Brenner W, Greber I, Gudejko-Thiel J, et al:: Migration of renal carcinoma cells is dependent on protein kinase Cdelta via beta1 integrin and focal adhesion kinase. Int J Oncol. 2008; 32(5): 1125-31. PubMed Abstract | Publisher Full Text

96. F Huo Y, Chen W, Zheng X: ROS, MAPK/ERK and PKC play distinct roles in EGF-stimulated human corneal cell proliferation and migration. Cell Mol Biol (Noisy-le-grand). 2015; 61(7): 6-11.

PubMed Abstract | F1000 Recommendation

97. Singh R, Lei P, Andreadis ST: PKC-delta binds to E-cadherin and mediates EGF-induced cell scattering. Exp Cell Res. 2009; 315(17): 2899-913. PubMed Abstract | Publisher Full Text

98. Kermorgant S, Zicha D, Parker PJ: PKC controls HGF-dependent c-Met traffic, signalling and cell migration. EMBO J. 2004; 23(19): 3721-34. PubMed Abstract | Publisher Full Text | Free Full Text

99. $\mathrm{F}$ Jiang $\mathrm{M}$, Qin $\mathrm{C}$, Han M: Primary breast cancer induces pulmonary vascular hyperpermeability and promotes metastasis via the VEGF-PKC pathway. $\mathrm{Mol}$ Carcinog. 2016; 55(6): 1087-95. PubMed Abstract | Publisher Full Text | F1000 Recommendation

100. F Su Al, Wiltshire T, Batalov $\mathrm{S}$, et al.: $\mathbf{A}$ gene atlas of the mouse and human protein-encoding transcriptomes. Proc Natl Acad Sci U S A. 2004; 101(16) $6062-7$

PubMed Abstract | Publisher Full Text | Free Full Text | F1000 Recommendation

101. Wu C, Orozco C, Boyer J, et al:: BioGPS: an extensible and customizable portal for querying and organizing gene annotation resources. Genome Biol. 2009; 10(11): R130.

PubMed Abstract | Publisher Full Text | Free Full Text

102. Chang BY, Chiang M, Cartwright CA: The interaction of Src and RACK1 is enhanced by activation of protein kinase $C$ and tyrosine phosphorylation of RACK1. J Biol Chem. 2001; 276(23): 20346-56. PubMed Abstract | Publisher Full Text

103. Ivaska J, Vuoriluoto K, Huovinen T, et al.: PKCepsilon-mediated phosphorylation of vimentin controls integrin recycling and motility. EMBO J. 2005; 24(22): 3834-45. PubMed Abstract | Publisher Full Text | Free Full Text

104. Eriksson JE, Dechat $\mathrm{T}$, Grin $\mathrm{B}$, et al.: Introducing intermediate filaments: from discovery to disease. J Clin Invest. 2009; 119(7): 1763-71. PubMed Abstract | Publisher Full Text | Free Full Text

105. F Pasapera AM, Plotnikov SV, Fischer RS, et al:: Rac1-dependent phosphorylation and focal adhesion recruitment of myosin IIA regulates 
migration and mechanosensing. Curr Biol. 2015; 25(2): 175-86. PubMed Abstract | Publisher Full Text | Free Full Text | F1000 Recommendation

106. F Ho CY, Jaalouk DE, Vartiainen MK, et al.: Lamin A/C and emerin regulate MKL1-SRF activity by modulating actin dynamics. Nature. 2013; 497(7450): $507-11$.

PubMed Abstract | Publisher Full Text | Free Full Text | F1000 Recommendation

107. F Jiu Y, Lehtimäki J, Tojkander S, et al.: Bidirectional Interplay between Vimentin Intermediate Filaments and Contractile Actin Stress Fibers. Cell Rep. 2015; 11(10): 1511-8.

PubMed Abstract | Publisher Full Text | F1000 Recommendation

108. Gruenbaum Y, Aebi U: Intermediate filaments: a dynamic network that controls cell mechanics. F1000Prime Rep. 2014; 6: 54 . PubMed Abstract | Publisher Full Text | Free Full Text

109. Oltean S, Bates DO: Hallmarks of alternative splicing in cancer. Oncogene. 2014; 33(46): 5311-8. PubMed Abstract | Publisher Full Tex

110. Irimia $\mathrm{M}, \mathrm{Blencowe} \mathrm{BJ}$ : Alternative splicing: decoding an expansive regulatory layer. Curr Opin Cell Biol. 2012; 24(3): 323-32. PubMed Abstract | Publisher Full Text

111. Toutant M, Costa A, Studler JM, et al:: Alternative splicing controls the mechanisms of FAK autophosphorylation. Mol Cell Biol. 2002; 22(22): 7731-43. PubMed Abstract | Publisher Full Text | Free Full Text

112. Patel NA, Kaneko S, Apostolatos HS, et al.: Molecular and genetic studies imply Akt-mediated signaling promotes protein kinase Cbetall alternative splicing via phosphorylation of serine/arginine-rich splicing factor SRp40. J BiOl Chem. 2005; 280(14): 14302-9. PubMed Abstract | Publisher Full Text

113. Armulik A: Splice variants of human beta 1 integrins: origin, biosynthesis and functions. Front Biosci. 2002; 7: d219-27. PubMed Abstract | Publisher Full Text

114. Fuchs $\mathrm{P}$, Zörer M, Rezniczek GA, et al.: Unusual 5' transcript complexity of plectin isoforms: novel tissue-specific exons modulate actin binding activity. Hum Mol Genet. 1999; 8(13): 2461-72. PubMed Abstract | Publisher Full Text

115. van Rossum AG, de Graaf JH, Schuuring-Scholtes E, et al:: Alternative splicing of the actin binding domain of human cortactin affects cell migration. $J$ Biol Chem. 2003; 278(46): 45672-9. PubMed Abstract | Publisher Full Tex

116. F Kumbrink J, Soni S, Laumbacher B, et al:: Identification of Novel Crkassociated Substrate ( $130^{\mathrm{cas}}$ ) Variants with Functionally Distinct Focal Adhesion Kinase Binding Activities. J Biol Chem. 2015; 290(19): 12247-55

PubMed Abstract | Publisher Full Text | Free Full Text | F1000 Recommendation

117. Nowak DG, Woolard J, Amin EM, et al.: Expression of pro- and anti-angiogenic isoforms of VEGF is differentially regulated by splicing and growth factors. J Cell Sci. 2008; 121(Pt 20): 3487-95.

PubMed Abstract | Publisher Full Text | Free Full Text

118. Philippou A, Armakolas A, Koutsilieris M: Evidence for the Possible Biological Significance of the igf-1 Gene Alternative Splicing in Prostate Cancer. Front Endocrinol (Lausanne). 2013; 4: 31

PubMed Abstract | Publisher Full Text | Free Full Text

119. Khan ZA, Chan BM, Uniyal S, et al: EDB fibronectin and angiogenesis -- a novel mechanistic pathway. Angiogenesis. 2005; 8(3): 183-96.

PubMed Abstract | Publisher Full Text

120. Bordeleau F, Califano JP, Negrón Abril YL, et al.: Tissue stiffness regulates serine/arginine-rich protein-mediated splicing of the extra domain Bfibronectin isoform in tumors. Proc Natl Acad Sci U S A. 2015; 112(27): 8314-9. PubMed Abstract | Publisher Full Text | Free Full Text

121. F Mouw JK, Yui $Y$, Damiano $L$, et al: Tissue mechanics modulate microRNAdependent PTEN expression to regulate malignant progression. Nat Med. 2014; 20(4): 360-7.

PubMed Abstract | Publisher Full Text | Free Full Text | F1000 Recommendation

122. Tang J, Ahmad A, Sarkar FH: The role of microRNAs in breast cancer migration, invasion and metastasis. Int $J$ Mol Sci. 2012; 13(10): 13414-37. PubMed Abstract | Publisher Full Text | Free Full Text

123. F Ellison D, Mugler A, Brennan MD, et al: Cell-cell communication enhances the capacity of cell ensembles to sense shallow gradients during morphogenesis. Proc Natl Acad Sci U S A. 2016; 113(6): E679-88.

PubMed Abstract | Publisher Full Text | Free Full Text | F1000 Recommendation

124. Kreeger $\mathrm{PK}$, Wang $\mathrm{Y}$, Haigis $\mathrm{KM}$, et al:: Integration of multiple signaling pathway activities resolves K-RAS/N-RAS mutation paradox in colon epithelial cell response to inflammatory cytokine stimulation. Integr Biol (Camb). 2010; 2(4): 202-8.

PubMed Abstract | Publisher Full Text | Free Full Text

125. F Gordonov S, Hwang MK, Wells A, et al:: Time series modeling of live-cell shape dynamics for image-based phenotypic profiling. Integr Biol (Camb). 2016 8(1): 73-90.

PubMed Abstract | Publisher Full Text | F1000 Recommendation

126. Wagner JP, Wolf-Yadlin A, Sevecka M, et al.: Receptor tyrosine kinases fall into distinct classes based on their inferred signaling networks. Sci Signal. 2013; 6(284): ra58.

PubMed Abstract | Publisher Full Text | Free Full Text

127. Janes KA, Lauffenburger DA: Models of signalling networks - what cell biologists can gain from them and give to them. J Cell Sci. 2013; 126(Pt 9): 1913-21. PubMed Abstract | Publisher Full Text | Free Full Text

128. F Huang B, Jolly MK, Lu M, et al:: Modeling the Transitions between Collective and Solitary Migration Phenotypes in Cancer Metastasis. Sci Rep. 2015; 5: 17379 .

PubMed Abstract | Publisher Full Text | Free Full Text | F1000 Recommendation 


\section{Open Peer Review}

\section{Current Peer Review Status:}

\section{Editorial Note on the Review Process}

Faculty Reviews are review articles written by the prestigious Members of Faculty Opinions. The articles are commissioned and peer reviewed before publication to ensure that the final, published version is comprehensive and accessible. The reviewers who approved the final version are listed with their names and affiliations.

\section{The reviewers who approved this article are:}

\section{Version 1}

\section{Gaudenz Danuser}

${ }^{1}$ Department of Cell Biology, University of Texas Southwestern Medical Center, Dallas, TX, USA

2 Department of Bioinformatics, University of Texas Southwestern Medical Center, Dallas, TX, USA Competing Interests: No competing interests were disclosed.

\section{Anand Asthagiri}

1 Department of Chemical Engineering, Northeastern University, Boston, MA, USA

2 Department of Bioengineering, Northeastern University, Boston, MA, USA

Competing Interests: No competing interests were disclosed.

\section{Comments on this article}

\section{Version 1}

Reader Comment ( F1000Research Advisory Board Member ) 26 Jul 2016

Robert Insall, CR-UK Beatson Institute for Cancer Research, UK

One of the real limitations of this field is the looseness of the term "contractility". Different authors use it to mean different things for different cell types, based on different types of evidence.

Can you do the field a favour and set out a decent definition? Even if you're not $100 \%$ confident it could prod the field into a consensus.

Competing Interests: none 
The benefits of publishing with F1000Research:

- Your article is published within days, with no editorial bias

- You can publish traditional articles, null/negative results, case reports, data notes and more

- The peer review process is transparent and collaborative

- Your article is indexed in PubMed after passing peer review

- Dedicated customer support at every stage

For pre-submission enquiries, contact research@f1000.com 